\title{
A tulajdonnevek jelentésszerkezete funkcionális kognitív keretben*
}

\author{
RESZEGI KATALIN
}

\section{Bevezetés}

A tulajdonnevek kapcsán, mint az ismeretes, napjainkban is az egyik központi kérdés a nyelvtudományon belül, hogy van-e jelentésük, és ha igen, hogyan írható le. A problémát lényegében az okozza, hogy a nyelvészeti gondolkodásmódot is meghatározó egyes filozófiai irányzatok és a formális nyelvészet képviselöi egyaránt olyan módon igyekeznek választ adni erre a kérdésre (és olyan módon határozzák meg a jelentést), hogy nem veszik figyelembe a nevek tényleges használatát, a természetes nyelvhasználatot. A filozófusok elsősorban a logikai állítások (propozíciók) igazságtartalma szempontjából foglalkoznak a nevek jelentésével. A formális nyelvészek pedig úgy tekintenek a nyelvre, s ennek részeként a jelentésre, mint ami elkülöníthető az embertől, a beszélőktől, a tényleges nyelvhasználattól. ${ }^{1}$

A jelen kor egyik olyan jelentős nyelvészeti irányzata, amely az embertől, az ember biologikumától nem elkülönítve igyekszik vizsgálni a nyelvhasználatot, a kognitív tudományok közé tartozó kognitív nyelvészet. Ez a fajta funkcionális kognitív közelítésmód persze nem teljesen új a nyelvtudományon belül, ${ }^{2} \mathrm{~s}$ egyáltalán nem idegen a névkutatástól sem — gondoljunk csak például a magyar névkutatáson belül a LÖRINCZE LAJOS nevéhez kötődő névlélektani irányzatra (1947) —, koherensnek mondható elméletté azonban csak a 20. század 70-es-80-as éveitől vált. A névkutatáson belül pedig lényegében csak a 2000-es évektől törekednek a kutatók deklaráltan is ezt az elméleti keretet alkalmazni a névhasználat különböző

* A tanulmány a Magyar Tudományos Akadémia Bolyai János Kutatási Ösztöndíjának, valamint az Emberi Erőforrások Minisztériuma ÚNKP-2018-4 kódszámú Új Nemzeti Kiválóság Programjának támogatásával készült, az MTA-DE Magyar Nyelv- és Névtörténeti Kutatócsoport programja keretében.

${ }^{1}$ Ilyen módon értelmezhető az a felfogás, amely szerint a nevek jelentés nélküli elemek, csak referenciájuk (denotátumuk) van (KRIPKE 1972, DONNELLAN 1972).

${ }^{2}$ Vö. pl. Wilhelm von Humboldt nyelvmagyarázata vagy Hermann Paul asszociatív pszichologizmusa. 
sajátosságainak vizsgálata során (vö. pl. BRENDLER szerk. 2016, SJÖBLOM 2006, RESZEGI 2009, 2012). S bár ez az elméleti keret, különösen a funkcionálisnak nevezett irányzatok, a maga teljességében szándékszik leírni a nyelvet, a nyelvhasználat társas jellegéből adódó — többek között a szociolingvisztika által feltárt - sajátosságainak a leírása ezen belül még kevésbé van kidolgozva (az ilyen irányú törekvések megfogalmazásához és első megvalósulásához lásd PÜTZ-ROBINSON-REIF szerk. 2014, illetve pl. FEHÉR 2018). Írásomban a nevek jelentésével összefüggésben azt mutatom be, hogy miként alkalmazható a funkcionális kognitív szemléletmód, illetve hogy milyen további szempontokkal szükséges bővíteni a jelenlegi leírást, hogy a névhasználat lehetőség szerint minden aspektusát magyarázni tudjuk. Ezzel pedig egyúttal azt is igyekszem szemléltetni, hogy miként illeszthetők a szociolingvisztikai és a kognitív nyelvészeti elméletek és eredmények egymáshoz.

A nevek jelentésének megítélése a névkutatáson — legalábbis a magyar névkutatáson - belül az utóbbi évtizedekben jórészt egységes volt, a nevekkel foglalkozó szakemberek ugyanis egyetértettek abban, hogy a neveknek van jelentésük, csupán a nevek jelentésszerkezetéről gondolkodtak esetleg némileg eltérően. A legkidolgozottabb és legismertebb jelentéselmélet J. SoltÉsz KATALIN nevéhez köthető, aki a nevek komplex jelentésstruktúráját vázolta fel (1979). Amint majd látni fogjuk, lényegében hasonló eredményre juthatunk a funkcionális kognitív elméleti keretet alkalmazva is, amiért mégis érdemes újragondolnunk a kérdést, az az, hogy ilyen módon jobban beilleszthetők a névtudomány eredményei a nyelvtudomány fősodrába, s ezzel együtt a kognitív tudományok (a kognitív pszichológia, a neuropszichológia stb.) nevekre vonatkoztatható eredményei is hatékonyabban hasznosíthatók a névkutatás számára.

\section{Kognitív szemantika}

Nézzük tehát, hogyan vélekedik a kognitív nyelvészet, ${ }^{3}$ illetve a kognitív nyelvészet fö irányzata(i) a jelentésröl!

Ehhez a kognitív tudományoknak abból az alapvetéséből kell kiindulnunk, hogy a kognitív képességek, köztük a nyelvhasználat s annak részeként a névhasználat is végső soron az agy, az idegrendszer produktuma, az elme, a mentális rendszer egyik funkciója; azaz a nyelvnek, s így a neveknek a feldolgozása is az elmében, a megismerő rendszerben zajlik. A kognitív tudományok egyik meghatározó (holista) irányzata szerint pedig a nyelv egyike a megismerési folyamatoknak, nem független az elme más folyamataitól. A nyelv elemei, a szavak, illetve a megismerési folyamat eredményeként kialakuló fogalmak között szerves, szételemezhetetlen kapcsolat van.

\footnotetext{
${ }^{3}$ A továbbiakban csupán a kognitiv jelzővel utalok a funkcionális kognitív irányzatokra.
} 
A kognitív nyelvészet a nyelv leírásakor a kognitív pszichológia elveire és eredményeire támaszkodik, azaz abból indul ki, hogy a nyelvi tudást is alapvetően meghatározzák a kognitív képességek és a kognitív korlátok, illetve hogy az általános megismerési mechanizmusok a nyelvi elemek jelentésszerkezetében is érvényesülnek. A nyelvhasználat célja, lényege pedig a jelentésalkotás, a nyelvi kifejezéseknek tehát központi része a szemantikai szerkezet (vö. LANGACKER 1987, 1991). Az elme és a nyelv szerves kapcsolatából kiindulva úgy vélik, hogy a nyelvi reprezentációk, a szavak jelentése szorosan összefügg a világról való tudással. A jelentés eszerint a fogalmi reprezentációkon alapul, azaz végső soron tapasztalati alapú. Maguk a fogalmi reprezentációk ugyanis az érzékszervekkel felfogott perceptuális inputok alapján jönnek létre olyan módon, hogy a megismerési folyamat során az észlelések fontos elemeit az elme kiválasztja és sémákba rendezi. A fogalmi reprezentáció tehát $-\mathrm{s}$ így a jelentés is - a világról való ismeretek elrendeződésével, prototípuselven müködő kategorizációjával épül ki és konvencionálódik (vö. TOLCSVAI NAGY 2017a: 35-41). E bizonyos mértékig rögzült (ugyanakkor továbbra is dinamikus hálózatot alkotó) sémák feleltethetők meg a fogalmainknak. S gyakorlatilag e sematikus fogalmi reprezentációk azok, amelyek egy-egy hangsor-reprezentációval, fonológiai szerkezettel szervesen összekapcsolódva jelentésként funkcionálnak. A jelentés tehát fogalmi alapú, s az ismeretelemek egyfajta hálózataként értelmezhető. (A fogalmi reprezentációk és a szóreprezentációk szerves összefonódását a kognitív idegtudomány eredményei egyértelmúen alátámasztani látszanak, KIEFER-PULVERMÜLLER 2012. ${ }^{4}$ )

A jelentés szempontjából a kognitív szemantika szerint meghatározó továbbá az is, hogy a fogalmakat a fogalmi rendszerben nem rendezetlenül tároljuk. Amint azt a pszicholingvisztikai kísérletek sokasága mutatja (vö. HONBOLYGÓ 2008: 66-74), a tapasztalataink szerint a világban együtt előforduló, egymással kapcsolatban álló, egymáshoz közel elhelyezkedő dolgok a fogalmi térben is közel helyezkednek el egymáshoz, fogalmi tartományokba (fogalmi keret, kognitív modell, idealizált kognitív modell) szerveződnek, s egy fogalmi tartományon belül a reprezentációk között erős kapcsolatot tételezhetünk fel. Ebből adódóan egy szó feldolgozásakor a velük kapcsolatban álló reprezentációk egy része is aktiválódik (szemantikai előfeszítés, vö. i. m. 72), például a DIÁK fogalma aktiválja a TANÁR, ISKOLA, FELELÉS stb. fogalmakat is. Épp a reprezentációknak erre a fajta rendeződésére támaszkodunk az újabb helyzetek, események és persze a kifejtett vagy

\footnotetext{
${ }^{4}$ Amennyiben agyi szinten valóban kimutatható ez a kapcsolat, akkor a mentális rendszer szintjén is hasonló müködést célszerü feltételeznünk. Még akkor is így érdemes eljárnunk, ha a két szint nyilvánvalóan nem mosható egybe, és nem feleltethető meg egymásnak egyértelmüen, illetve még ha elvileg a nyelvi modellekkel szemben nem is elvárás a modellálni kívánt folyamattal való teljes fokú strukturális és funkcionális megfelelés; minél nagyobb fokú ez a megfelelés, a reprodukálás, annál inkább valószínüsíthető, hogy a vizsgált folyamat hasonlóan müködhet.
} 
nem explicit megnyilatkozások feldolgozásakor. (Ezért nem szükséges minden egyes iskolához kapcsolódó szituációban vázolnunk, hogy hogyan is müködik az iskola, a tanár-diák viszony.) A jelentés leírásakor ezekre a kapcsolatokra is tekintettel kell lennünk, hiszen egyes szavak jelentése csak más fogalmakon keresztül értelmezhető: például a könyök szó jelentéséhez a KÖNYÖK fogalom mellett a FELKAR, KAR, TEST stb. fogalmakat is aktiválnunk kell (vö. LANGACKER 2008: 46-50, TOLCSVAI NAGY 2017b: 218-222).

A fogalmi tartomány (fogalmi keret) terminus emellett sokkal elemibb - tovább már nem elemezhető - ún. alap szinten is értelmezhető: az egyes fogalmak, fogalmi kategóriák megalkotásában szerepet játszó ismeretelemek a kognitív szemantika szerint szintén fogalmi tartományokba rendeződnek. A kés szó jelentése például olyan módon értelmezhető, hogy aktiválom a késekre jellemző alakot az ALAK fogalmi tartományon belül, a késekre jellemző funkciót a KANONIKUS FUNKCIÓ fogalmi tartományon belül stb. (vö. LANGACKER 1991: 5). S ezek közül — a kognitív pszichológia és az idegtudomány vizsgálatai szerint — vannak dominánsabbak és kevésbé jelentősek az adott fogalom meghatározásában (például a kognitív pszichológiai és neuropszichológiai vizsgálatok szerint az állatok esetében a külső jegyek, az alak meghatározóbb, míg a használati tárgyak esetében a többi mellett valamivel erőteljesebben aktiválódik a funkciót reprezentáló agyi terület, vö. KIEFER-PULVERMÜLLER 2012: 806). E közelítésmód lényege tehát, hogy az ismeretelemek, tulajdonságok nem önmagukban jellemzik az adott fogalmakat — ezért is nem lehet szükséges és elégséges feltételekkel leírni a szavak jelentését -, mindig más elemekhez, tulajdonságokhoz viszonyítva értelmezhető egy-egy fogalom (egyfajta elötér-háttér viszonyban, vö. az alaklélektan elvei, BERNÁTH-RÉVÉSZ 2002: 47-51, a kognitív nyelvészetben való alkalmazásához lásd LANGACKER 2008: 57-60). Mindebből adódóan a kognitív szemantika felfogásában a szavak jelentése fogalmi tartományokban elrendezett absztrahált tulajdonságok hálózataként írható le.

A szavak jelentésének alapját adó fogalmi reprezentációk kapcsán hangsúlyoznunk kell azt is, hogy ezek a reprezentációk szubjektívek, azaz egyéniek, hiszen az egyén a saját tapasztalataiból vonja el ezeket. Mindenkinek részben kicsit más tapasztalatai vannak már a legalapvetőbb dolgokról, például a székekről, könyvekről, házakról, kisautókról stb. is, s ennek következtében az egyének mentális rendszerében némileg másként reprezentálódnak ezek a fogalmak. Emellett kulturális, szociokulturális különbségekkel is számolhatunk, a nyelv ugyanis egy adott kultúrához kötődően alakul, egy adott kultúrában konvencionálódik és örökítődik tovább a szocializáció során (LANGACKER 1999: 15-16, TOLCSVAI NAGY 2015: 12, CIENKI 2007). A szubjektivitás más oldalról olyan módon is megjelenik, hogy a világról való ismeretszerzés többnyire nem érzelmileg semleges folyamat. A fogalmak, illetve áttételesen a szavak reprezentációjában pedig gyakran 
ezek az érzelmek, értékítéletek is rögzülnek (a szavak, fogalmak bizonyos csoportjaihoz ez jobban hozzátartozik, míg másokhoz kevésbé, KIEFER-PULVERMÜLLER szerint például fokozottan számolhatunk velük az absztrakt fogalmak idegrendszeri megalapozásában, 2012). A szubjektív fogalmi reprezentációkat többek között épp a nyelvhasználat közelíti egymáshoz. ${ }^{5}$

A nyelvhasználatra jellemző továbbá a perspektiváltság, azaz hogy „egy dolog vagy folyamat különböző megközelítésekböl konceptualizálható" (TOLCSVAI NAGY 2010: 34). Ez részben már a szavak szintjén is megragadható, a szavak is valamilyen nézöpontot tükröznek, ez azt jelenti, hogy a nyelvi kifejezések „olyan szociális konvenciók, amelyekkel másokat arra késztetünk, hogy egy tapasztalati helyzetet egy meghatározott perspektívából szemléljenek" (TOMASELLO 2002: 127). Ugyanarra a dologra például különböző szintü kategorizációs megjelöléssel utalhatunk a közlés funkciójának megfelelően (pl. irodai szék, szék, bútor, tárgy), vagy ugyanazt a valóságdarabot a szerepei szerint többféleképpen jelölhetjük (anya, nö, lány, asszony, háziasszony stb., kislány, kislányom, nagycsoportos, leendö elsős, nagytesó vagy növér stb., és persze utalhatok rá a nevével is, bár ez nem igazán kerül elő a szakirodalomban). Mindegyik megjelölés a beszélők által ismert komplex fogalom egy részére irányítja a figyelmet a beszélő és az általa említett személy viszonyában. A szavak jelentéshálózatai, illetve a köztük lévő kapcsolatok reprezentálják ezeket az ismereteket, ez tehát már a szavak konvencionált jelentésének része, azaz kontextus nélkül is felfejthetö (TOLCSVAI NAGY 2017b: 265-266).

\section{A tulajdonnevek jelentése kognitív megközelítésben}

A kognitív szemantika szerint a nyelvi közlés lényegi funkciója, hogy hozzáférhetővé tegyen valamilyen értelmes tartalmat, azaz minden nyelvi megnyilatkozás jelentést közöl, s természetszerüen minden kisebb nyelvi elemnek, szavaknak, morfémáknak, kifejezéseknek stb. is van jelentése. A tulajdonnév a dologmegjelölések egyik formája, akárcsak a köznevek, s a neveknek is e n c i kl o p é dikus jele n tés e van, amely szintén fogalmi tartományokban elrendezett absztrahált tulajdonságok hálózataként értelmezhető (vö. TOLCSVAI NAGY 2008: 39). Ez azt jelenti, hogy a neveknek is kiterjedt mentális reprezentációja, fogalmi

\footnotetext{
${ }^{5}$ Míg a kognitív nyelvészet képviselői jórészt valóban mintegy egyenlőségjelet tesznek fogalom és jelentés közé (ebböl logikusan következik, hogy például LANGACKER szerint nem is számolhatunk nyelvi relativizmussal, vö. 1987: 55, lásd még ToLCSVAI NAGY 2013), addig akadnak olyan alternatív kognitív közelítésmódok, amelyek a fogalmi rendszer és a nyelvi rendszer szoros kapcsolata mellett is számolnak bizonyos fokú függetlenséggel (ehhez lásd PEDERSON 2007: 10211036). SzILÁGYI N. SÁNDOR szerint a nyelvünk is leképez egy valóságot azáltal, hogy az anyanyelvünk szavai, nyelvtani formái hogyan szegmentálják a valóságot, hogy a fogalmi kategorizációhoz képest a nyelvi kategorizáció szempontjából mely sajátosságok fontosak vagy kevésbé fontosak (1996: 36-40).
} 
jelentése, komplex jele n té s s zerke zete van, s a tulajdonneveket is a köznevekhez, más szavakhoz hasonlóan sajátítjuk el. A nevek kiterjedt mentális, idegrendszeri reprezentációját számtalan neurolingvisztikai vizsgálat alátámasztja (vö. RESZEGI 2014, 2017, 2018a).

A tulajdonnevek jelentésének ugyanakkor legmeghatározóbb sajátossága, hogy egyetlen entitásra vonatkozik, azaz egyetlen valóságdarabra vonatkozó ismeretek összessége alkotja a nevek fogalmi jelentésének alapját (ez az, amit hagyományosan denotatív vagy referenciális jelentésnek neveznek). ERNST HANSACK szerint ugyanakkor végső soron a tulajdonnevek feldolgozásakor is a közneveknél feltételezett absztrakciós és kategorizációs folyamatokkal számolhatunk, ám e folyamatok eredményeképpen egyelemű osztályok jönnek létre (2004). Így a tulajdonnevek egy része akár kontextus nélkül is be tudja tölteni kommunikációs azonosító funkcióját, azaz episztemikusan lehorgonyzott (TOLCSVAI NAGY 2017b: 361, a fogalomhoz lásd még 301-305, a diskurzusvilágbeli lehorgonyzáshoz vö. TÁTRAI 2017: 928-929). Bár természetesen nem ilyen módon, hanem megnyilatkozások részeként használjuk őket, mint bármely más nyelvi elemet, és persze a kontextus azonosító erejére a nevek kapcsán is szükség lehet, például a tulajdonnévi homonímia eseteiben. ${ }^{6}$ A neveknek ez a sajátossága a közszavakkal öszszevetve értelmezhető igazán. A köznevek ugyanis mindig dolgok egy csoportját, a kategóriát jelölik, s a köznév mindig adott beszédhelyzetben, a szövegben, kontextusban tölti be azonosító funkcióját, határozza meg egyértelmüen az általa jelölt kategória bizonyos elemét/elemeit.

A névelméleti munkákban épp ez alapján szokás a mentális lexikon két bizonyos mértékig elkülönülő részéről beszélni: azaz a lexikális jelentéssel is rendelkező közszói (köznévi) alhálózat mellett feltételezni egy bizonyos mértékig külön alhálózatként müködő tulajdonnévi (proprial) jelentésü / h a s z ná la t ú o n o m a s z t i k o n t (NYSTRÖM 2017: 41). Ez a két alhálózat azonban nem független egymástól, a neveket alkotó felismerhető közszói elemek révén kapcsolat van köztük. Ezt a feltételezett kapcsolatot egyértelmüen alátámasztják az ún. előfeszítéses (priming) kísérletek a családnevek kapcsán (VALENTINE-BRENNEN-BRÉDART 1996: 72), s persze más névfajtáknál is számolhatunk ezzel, noha esetükben ilyen vizsgálatokat még nem végeztek. Tehát amikor hallunk vagy olvasunk egy nevet, azaz névként dolgozunk fel egy hangsort vagy betüsorozatot, ez azonnal aktiválja a vele jelölt személlyel, hellyel stb. kapcsolatos ismereteinket (proprial meaning), s ezzel egy időben a névben felismert közszói elemek lexikális jelentése is aktiválódik, még ha a folyamatos tulajdonnévként (adott tulajdonnévfajtaként) való használatnak, s ezzel egyidejüleg a

${ }^{6}$ Találunk példát arra is, hogy bizonyos kultúrákban, amennyiben metonimikus névadással létrejött névazonosságról van szó, az ilyen kétértelmüségeket nem feltétlenül tartják szükségesnek tisztázni (vö. HoLTON 2011: 144, 150). 
köznévi feldolgozás elnyomásának rögzüléseképpen nem is túl erőteljesen. A nevek állománya, az onomasztikon tehát — az áttetsző névelemek révén — élő kapcsolatban van a mentális lexikon közszói elemeivel (vö. NYSTRÖM 2017: 42). (Erre a kapcsolatra utalnak a korábbi szakmunkák e t i mo ló g i a i j e le n t é s k é n t, vö. J. SOLTÉSz 1979. Ezzel kapcsolatban azonban érdemes utalni arra, hogy ezek ún. naiv etimológiák, a beszélők nyelvi ismeretein alapulnak, $\mathrm{s}$ nem feltétlenül esnek egybe a nyelvtörténeti kutatások eredményeivel.)

A tulajdonneveket ugyanakkor nem pusztán identifikációra használjuk. Noha nyilvánvalóan nem számolhatunk az esetükben olyan fajta kategóriamegjelöléssel, mint a közneveknél - amire gyakran lexikális jelentésként utalnak a szakirodalomban -, hasonló típusra utalás ( tí pu s j e le n té s/ ka t e g o r i á li s jelentés ) a tulajdonnevek esetében is van. A névmodellek, a nevek használatával kapcsolatos korábbi tapasztalatok alapján ugyanis tudjuk, hogy bizonyos névformák tipikusan személyeknek, bizonyos csoportok tagjainak vagy épp helyeknek, bizonyos helyfajtáknak a megjelölésére használatosak. Ez az oka annak, hogy egy lányt nem keresztelnek János-nak, egy fiút pedig Rózsá-nak (vö. TOLCSVAI NAGY 2008: 30, idézi CRUSE 2000: 317 példáját). E tudásunk alapján tehát egy tulajdonnevet hallva a feldolgozási, megértési folyamat első lépéseként a jelöltre vonatkozó ismeretek mellett azt is megállapítjuk, hogy az adott hangsor egy tulajdonnév; s arra is következtetünk, hogy egy ember vagy éppen egy hely stb. nevéröl van szó. Ebben a név formai sajátosságaira, illetve a kontextusra, a beszédhelyzetre támaszkodunk. Azt, hogy a típusra utalás is jelen van a tulajdonnevek jelentésszerkezetében, jól szemléltetik azok az esetek is, amikor egy ismeretlen, számunkra új nevet tartalmazó megnyilatkozást hallunk. LANGACKER példáját idézve, a Stan Smith névvel találkozva az első reakciónk annak megállapítása, hogy névvel van dolgunk, egy ember nevével (1991: 59), majd a névforma alapján — a nevekröl meglévő korábbi ismereteink, a nevekről meglévő sémáink, névmodellünk birtokában — következtetni tudunk a nevet viselő személy nemzetiségére, nemére stb., s ez aktivál(hat)ja is az idézett csoportra, esetünkben az angol férfiakra vonatkozó ismereteinket. A nevekben tehát egyszerre van jelen a típusra és az egyedre, a megvalósulásra utalás. ${ }^{7}$ A nevek kapcsán az elméleti úton,

${ }^{7}$ Bizonyos, különösen gyakori, tipikus vagy annak gondolt nevekhez olyan szorosan hozzátartoznak ezek a csoporthoz kapcsolódó ismeretek, olyan meghatározó tehát a név kapcsán a típusjelentés, hogy ezeknek a sztereotipikus ismereteknek a birtokában a név viselőjéről pusztán a neve alapján feltételezünk bizonyos tulajdonságokat. A típusjelentést jól szemlélteti az a kísérlet, melyben a résztvevőknek nőket kellett jellemezniük szeretetreméltóság, ambíció, intelligencia, jellem és szépség szempontjából a fényképük alapján. Két hónappal később megismételték a feladatot, ez alkalommal azonban a fotókhoz jellegzetes ír, olasz, zsidó, angolszász neveket is csatoltak a kutatók. Ekkor a nevek nemzetiségre, vallási hovatartozásra utaló jellemzői, illetve megszokottsága alapján egészen más személyiségjegyeket társítottak a fényképekhez, mint korábban (RAZNAN, idézi FORGÁCs 1999: 85), s egyértelmüen a nevekről tárolt ismeretek, a típusjelentés alapján alkottak véleményt a résztvevők. (További hasonló jellegü vizsgálatokhoz lásd M. HoRvÁTH 2014.) 
illetve a névhasználati szokások alapján feltételezett típusjelentést neurolingvisztikai eredmények is támogatják (vö. VAN LANGENDONCK 1999).

A nevek elsajátítása is erre a típusjelentésre épül: amikor először hallunk egy új névformát, a szituáció, a kontextus, valamint a nevekre vonatkozó korábbi ismereteink alapján, a típusspecifikáció eredményeként kialakul egy rendkívül sematikus elsődleges reprezentációja a névnek, a név fogalmi tartalmának. Ez az elsődleges reprezentáció azután a későbbi említések vagy konkrét tapasztalatok alapján további tulajdonságjegyekkel bővül. A nevek jelentése tehát nem csupán az azonosító funkció, hanem a részét képezi a név által jelölt entitásról tárolt valamennyi ismeretelem (asszociációk, konnotációk, érzelmek), azaz a közszavakéhoz hasonlóan enciklopédikus, fogalmi alapú. (Az asszociációk egy része nem a fogalomhoz kapcsolódik, hanem a hangsorhoz, bár esetenként nem is igazán lehet az asszociációkat ilyen módon elkülöníteni.) A tulajdonnevek jelentésszerkezete pedig a beszélők számára lehet teljesen sematikus, és lehet teljesen kidolgozott, az adott entitásról sok-sok ismeretet tartalmazó hálózat, sok közbenső változattal. A jelentés természetesen objektumfajtánként más-más típusú ismeretelemeket foglalhat magába. Míg a személyek esetében, mint láttuk, a nem, nemzetiség, vallás stb. fogalmi tartományok aktiválódnak, addig például városnevek esetében ilyenek a méret, földrajzi elhelyezkedés, szerkezet, jellegzetes épületek stb. (vö. TOLCSVAI NAGY 2008: 39). Ezeknek az ismeretelemeknek egy része egyéni, más része kisebb-nagyobb közösség számára ismert.

Egy-egy névformához tehát igen bőséges ismeretanyag kapcsolódhat, a típusjelentéssel bizonyos mértékig átfedésben többek között kulturális jellegü ismeretek is. S minthogy az egyén a neveket a társadalmi-nyelvi szocializációja során, a kultúra részeként ismeri meg, egy-egy név (az általa aktivált ismeretelemek révén) azonnal képes felidézni bizonyos hozzá asszociált, hozzá kötődő kulturális tartalmat (történeti vagy aktuális eseményt, néprajzi jellegzetességet stb.). A nevek esetében e kulturális ismeretelemek más nyelvi elemekkel összevetve különösen meghatározók. A köznevek fogalmi reprezentációját például sokkal közvetettebben befolyásolják a kulturális hatások, hiszen kategóriát jelölnek. A GYÜMÖLCS fogalmi kategória nyilvánvalóan mást jelentett ugyan a korábban élt emberek számára, a különböző gyümölcsfélékröl való tapasztalatok ugyanis koronként eltérők lehetnek, de a kategóriát meghatározó tulajdonságjegyek lényegében nem változtak (vö. TOLCSVAI NAGY 2017b: 297-298). Ugyanakkor például a helyet megjelölő nevek jelentésében közvetlenül jelennek meg a helyhez magához kapcsolódó ismeretek (elhelyezkedés, méret, jellegzetes épületek, történelmi események, lakosok, hozzá kötődő ismert emberek stb.). Ezért a neveket minden más nyelvi elemnél erősebben jellemzi a kultúrával való összefüggésük. HOFFMANN ISTVÁN szerint mindezek fényében a névhasználat legalább annyira kulturális, mint nyelvi kérdés, s külön jelentés-összetevőként különíti el a nevek 
kulturális je le n té sé t, ami az enciklopédikus jelentésként meghatározott hálózat egy részeként értelmezhető (2010: 51-53). Az Eger településnév például a magyar emberek számára aktivál olyan történelmi ismereteket, mint az egri vár törökök általi ostroma a 16. században, a magyarok győzelmét Dobó István vezetésével, aktiválja továbbá az egri vár, az egri minaret képét, az egri borok fogalmát (esetleg ízének, illatának emlékét), illetve az Egri csillagok című regényröl való ismereteinket. Persze az ott élök számára az Eger helynév reprezentációja jóval kidolgozottabb, számos további, konkrét tapasztalaton alapuló ismeretet tartalmaz. Ezek a kulturális ismeretelemek a hely, s így a helynév reprezentációjának szerves részei.

A tulajdonneveknek tehát olyan komplex mentális reprezentációja van, amely a szóformára és a szó használati sajátosságaira vonatkozó ismeretelemek mellett magába foglalja a név által jelölt entitásra vonatkozó ismereteket is, $\mathrm{s}$ amelyben egyszerre vannak jelen a típusra és a konkrét jelöltre vonatkozó ismeretelemek. ${ }^{8}$

\section{A nevek jelentésszerkezetének további elemei}

A névhasználatnak, illetve általában véve a nyelvhasználatnak több olyan sajátossága is van, amelyek szintén magyarázhatók a vázolt funkcionális kognitív közelítésmóddal, noha azok ebben az elméleti keretben eddig ezek jobbára még nem kerültek a kutatások fókuszába.

${ }^{8}$ Mivel a magyar névkutatók viszonylag gyakran utalnak SzILÁGYI N. SÁNDOR nyelvi világmodelljére, érdemes kitérnünk arra is, hogy SzILÁGYI N. alternatív kognitív jelentéselmélete hogyan viszonyul a vázolt kognitív szemantikához. SzILÁGYI N. a jelentést nem a szavak felöl, hanem a dolgok felől értelmezi, azt igyekszik meghatározni, hogy melyek azok a nyelvi észlelési feltételek, amelyek alapján egy dolgot adott szóval jelölünk. S ezek alapján vizsgálja a szavak komponencialitását (hány és milyen komplex jelentés-összetevő alapján történik a nyelvi kategorizáció, az adott entitásnak a megnevezése), s különíti el a különböző jelentésszerkezetủ szavakat. Felfogása szerint a személynevek a legkevésbé komplex szerkezetü nyelvi elemek, az esetükben még kategorizáció sincs, „sokan vannak ugyan, akiket Mariskának hívnak, de mindegyiküket külön-külön hívják így, és nem mint a »Mariska« kategória tagjait. Ilyen kategória nincs is, a $M a$ riskák nem alkotnak olyan kategóriát, amelyröl ha tudjuk, mik a meghatározó jegyei, akkor az utcán azonnal meg tudjuk mondani, ki Mariska, és ki nem. Ezt minden egyes személyre külön tanuljuk meg, éspedig úgy, hogy megjegyezzük az arcát, és azt, hogy ehhez az archoz a Mariska név tartozik." (2004). Ez a fajta közelítésmód lényegében a denotatív jelentésnek nevezett jelentésre fókuszál, és nincs tekintettel arra, hogy a szavak reprezentációjában más jellegü ismeretek is tárolódnak; lényegében tehát csak a LANGACKER által absztrahált sematikus tulajdonságjegyeket veszi figyelembe, amik a modellben a nyelvi minősítés ismérveinek együtteseként jelennek meg (1996: 39). A szintén kognitív közelítésmódot alkalmazó WILLY VAN LANGENDONCK ugyanakkor névelméletében a nevek komplex jelentésszerkezetével számol: noha a neveknek nincs a köznevekhez hasonló lexikális jelentése, van azonban ún. preszuppozicionális jelentése, amelynek több összetevője van: kategoriális jelentés (típusjelentés), asszociatív jelentés, emotív és grammatikai jelentés (2007: 87). 


\subsection{Név és identitás}

A neveknek az identitásban, az identitásformálásban játszott szerepe közismert. ${ }^{9}$ Úgy tünik, hogy a kognitív szemantika közelítésmódjával, a komplex jelentésszerkezet - az enciklopédikus tudással, a fogalommal való szerves kapcsolat - feltételezésével jól magyarázható a neveknek ez a funkciója.

Név és identitás kapcsolatában mindenekelőtt a saját névnek a személyiség azonosításában, illetve esetleg az identitásjelzésben, valamint az identitás formálásában játszott szerepe juthat eszünkbe. A saját név identitásépítésben való részvételének mértéke ugyanakkor a kognitív pszichológiai kutatások szerint kultúránként és egyénenként jelentős különbségeket mutat (vö. BRENNEN 2000).

A racionalista, materialista európai kultúrkörben a személynevet általában egyfajta címkének tekintik, amely fontos szerepet tölt be a személyiség azonosításában, de a személyiség alakulását a többség esetében általában nem befolyásolja. Itt is jelen van azonban az egyének egy részének gondolkodásában a név identitásalkotó és -befolyásoló hatása. József Attila például így ír önéletírásában: „A harmadikos olvasókönyvben azonban érdekes történeteket találtam Attila királyról és rávetettem magam az olvasásra. Nem csupán azért érdekeltek a hun királyról szóló mesék, mert az én nevem is Attila, hanem azért is, mert Öcsödön nevelöszüleim Pistának hívtak. A szomszédokkal való tanácskozás után a fülem hallatára megállapították, hogy Attila név nincsen. Ez nagyon megdöbbentett, úgy éreztem, hogy létezésemet vonták kétségbe." (Curriculum vitae, Tverdota 1992). A névnek az identitásalkotásban játszott ilyen mértékủ szerepe azonban — annak ellenére, hogy további példák is idézhetők rá - semmiképpen sem tekinthető általánosnak ebben a kultúrkörben. A modern társadalmakkal összevetve más kultúrák másként gondolkodnak a név jelentőségéről, funkciójáról általában véve (vö. pl. a kanadai indiánok névhasználati szokásairól FĂLĂUŞ-TODEA 2017). Az európai társadalmaktól eltérően másutt eleve más típusú névadás dominál: a listából választott, alapvetően referáló funkciójú nevek helyett több kultúrában leíró, sajátosságjelölő neveket használnak, s a névhez kötődő hiedelmek, a névnek tulajdonított funkció is eltérö.

A nevekről, a nevek nyelvi felépítéséről, funkcionálásáról, az identitás és a közösség életében betöltött szerepéről, a névadási szokásokról való tudást a szocializáció-kulturalizáció részeként a közösség tagjaként tanulja meg az egyén. Az ilyen módon kiépülő névkompetencia (a mentális lexikonban tárolt nevekből absztrahálható sémákon, a névmodellen alapulva) — a nevekről való különböző típusú tudásösszetevők mellett — ismereteket tartalmaz a saját név szerepéről

${ }^{9}$ Ezt a kérdést jórészt a névviselő személy nézőpontjából közelítik meg a szakemberek, noha nyilvánvalóan alkalmazható egy külső nézőpont, a névhasználók nézőpontja is (ALDRIN 2017:383), ami szintén tovább tagolható a szociális kapcsolatok távolsága alapján. 
is. ${ }^{10}$ A névkompetencia kiépülésének részeként alakul tehát a saját névhez való viszony is.

A saját névhez való viszonyban megmutatkozó kulturális és egyéni különbségek ellenére úgy tünik, e névforma neurális feldolgozása mégis általában véve kitüntetett szerepü. A neuropszichológiai kutatások szerint mindenkire jellemző, hogy másként reagál az agyunk a saját nevünkre, mint más személynevekre. Ez a sajátosság már igen korai életkorban megfigyelhető. TINCOFF és JUSCZYK kutatásai szerint a kicsik kb. hat hónapos koruktól képesek különbséget tenni tulajdonnevek és köznevek között $(1999,2000)$, más kísérletek szerint ugyanakkor a saját nevüket már négy-öt hónapos babák is preferálják (MANDEL-JUSCZYKPISONI 1995, JUSCZYK-MANDEL 1996: 36-37). A saját névnek ez a kitüntetett szerepe pedig később is megmarad: egyfüles hallási feladat során más keresztnevekhez képest is szignifikánsan gyorsabban dolgozzuk fel ezt (MULLER-BOVET 2002), s alvás közben is sajátosan reagál rá az agy más nyelvi elemekkel összevetve (BASTUJI-PERRIN-GARCIA-LARVEA 2002), a saját név jelentőségét legutóbb egypetéjü ikrek esetében is bizonyították (BRÉDART 2018).

Mindez olyan módon értelmezhető, hogy a saját név aktiválja a személyiség szempontjából központi jelentőségü ÉN fogalmi tartományt, az ÉNről, a sajátmagamról való ismeretek komplexét (testkép, csoporthoz tartozás tudata, fontosnak tartott értékek, emlékek, az életút egysége stb.). Azokban a kultúrákban pedig, melyekben a neveket nem csupán egy szimbolikus jelrendszernek tekintik, hanem azt feltételezik, hogy a szavak, a nevek maguknak az általuk jelölt dolgoknak a szerves részei (vö. gyerekkori nominális realizmus, ${ }^{11}$ PIAGET 1965), a saját névnek is nyilvánvalóan sokkal fontosabb szerepet tulajdonítanak az én, az identitás alakulásában.

A saját név mellett ugyanakkor más nevek és más névfajták, köztük a helynevek is szerepet játszanak az identitás, identitástudat alakításában, még ha nem is olyan jelentős mértékben, mint a saját név. Ennek szintén a nevek komplex jelentésszerkezete teremti meg az alapját: a nevek és az egész mentális rendszer hálózatelvü szerkezetével magyarázható, hogy a különböző csoportok reprezentációjához hozzátartoznak a nevek is. A nevek pedig ebből adódóan nem csupán mint nyelvi elemek, hanem mint a kultúra hordozói, közvetítői is értelmezhetők. Ilyen módon magyarázható, hogy egy-egy, az adott kultúra szempontjából jelentős személy- vagy helynév képes az összetartozás érzését előidézni, a kollektív emlékek

${ }^{10}$ A névmodell nem külön összetevő a mentális lexikon mellett, hanem a nevekről tárolt — a nevek reprezentációjából absztrahált — különböző típusú tudásösszetevők egyfajta összeszervezödése (séma).

${ }^{11}$ PIAGET szerint ez a fajta világértelmezés általánosan jellemzi a gyermeki fejlődést: az óvodás kori gondolkodás sajátossága, hogy a gyerekek elutasítják azt a lehetőséget, hogy a tárgyak elnevezései változtathatók, a szót az általa jelölt tárgy láthatatlan tulajdonságának tekintik (1965). 
felidézésével. Az ilyen gazdag kulturális ismeretanyagot magukba sürítő, felidéző nevek tehát hozzájárulnak a valahová (egy adott csoporthoz vagy területhez) tartozás érzéséhez.

A neveknek épp ebből a fajta meghatározottságából kiindulva teljességgel érthető az is, hogy miért vált ki ellenérzést az emberekből egy-egy közismert, kollektív emlékeket felidéző név megváltoztatása. BOTOLV HELLELAND ezzel öszszefüggésben Oslo példáját idézi: amikor 1924-ben a norvég főváros nevét (akkori Kristiania) visszacserélték a középkori Osló-ra, valóságos harcok bontakoztak ki. Mára ez a helyzet természetesen megváltozott, az Oslo név általánosan elfogadott, és a főváros jelképeként funkcionál (2009: 502). Hasonló ellenállást vált(hat) ki a nevek nyelvi arculatának megváltoztatása is.

A helynevek kulturális beágyazottságát és identitásalkotó szerepét támasztják alá az ULLA HAKALA és munkatársai által végzett finnországi felmérések. Ezek szerint a véletlenszerüen kiválasztott adatközlők jelentős hányada fontosnak tartja a lakóhelye nevét, s úgy érzik, hogy a lakóhely neve számít az egyéni és a csoportidentitás építésében (2015). A szemiotika felöl közelítve a kérdéshez hasonló megállapításra jutott MUELLER és SCHADE is. Véleményük szerint a helyek reprezentációjához hozzátartoznak a helyhez kapcsolódó kulturális ismeretek és egyéb asszociációk, a név pedig közvetíti ezeket az ismereteket. A név tehát a hely szimbólumának tekinthető, s mint ilyen, más szimbólumokhoz hasonlóan fontos szerepet játszik a csoportidentitás alkotásában (2012, a nevek identitásjelző funkciójáról lásd még többek között SAPAROV 2003, HOFFMANN 2010, 2014, AKSHOLAKOVA 2014, ALDRIN 2017, GYÖRFFY 2018: 27-39). ${ }^{12}$

A nevekhez asszociált, a nevek által felidézett (pozitív, negatív vagy semleges) kulturális, történelmi ismeretek, asszociációk, akár a névforma etimológiai jelentése vagy az általa előidézett konnotációk is fontos szerepet játszhatnak a nevet viselő objektum megítélésében. Például a Chicago városnév általában negatív asszociációkat vált ki, s ez a fajta sztereotípia a város attraktivitását mint lakóhely és mint turisztikai célpont is hátrányosan befolyásolja. A nevek komplex jelentésszerkezete révén ugyanakkor nemcsak ez, hanem a nevek használatában végbemenő változások is jól magyarázhatók. A Csikágó név például Magyarországon is több helyen használatban volt a 20. század első felében településrésznévként (SZABÓ T. 1934: 170). Budapest 19. század végén kiépített VII. kerületét is így nevezték sokáig, kezdetben a gyors felépítése, majd a közrend hiánya miatt.

${ }^{12}$ Ez a csoportidentitás a kutatók szerint éppen ezért fontos összetevő egy adott hely piacképessége (pl. a turizmus, befektetők, képzett munkaerő, diákok stb.) szempontjából is. A helynevek pedig, mint a helyek szimbólumai, márkanevekként müködnek, s szintén részei a brandstratégiának (Mueller-Schade 2012, vö. még Medway-Warnaby 2014). 


\subsection{Metonimikus, metaforikus használat és köznevesülés}

A vázolt komplex jelentésszerkezet — a kulturális ismereteket leképező ismeretelemek együttese - az alapja a nevek metonimikus és metaforikus használatának, illetve a köznevesülés folyamatának is. Az adott entitáshoz (személyhez, helyhez stb.) kapcsolódó ismeretelemek egyike vagy komplexe olyan dominánssá, általánosan ismertté válhat, hogy e típusra utaló jelentésmozzanata alapján a név aktuálisan köznévként, egy kategória megjelölésére használható és értelmezhető (RESZEGI 2018b). S amennyiben ez a jelentés — a közös elöismeretek alapján — mások számára is hozzáférhető, a szónak ez a fajta használata kiterjedtebbé válhat. Jó példa erre az előbb idézett Chicago városnév köznevesülése: pl. csikágó lesz 'tömeges bünözés lesz valahol, az amerikai mintára', lásd még például micsoda Einstein vagyok!, futball Einsteinek, patópálok, ébresztö!

A metonimikus kiterjesztés és a köznevesülés másik, jellemzően személynevekhez kötődő típusában nem egyetlen személy neve válik köznévvé, hanem lényegében egy a beszélők szerint adott (különböző alapon szerveződő, kisebb-nagyobb) csoporthoz kötődő, az adott csoporton belül gyakori, tipikus(nak tartott) nevet kezdenek el köznévként használni, s a csoporthoz tartozásra, vagy a csoport egy vagy több sztereotipikus sajátosságára utalva. Ebben az esetben a típusjelentésként megjelölt jelentéskomponens, a prototipikus névhasználatról reprezentált ismeretelemek szolgálnak a folyamat alapjául, s ezek felerősödésével a névformát a csoport egészének vagy a csoport valamely sajátosságának jelölésére használják, pl. a csajok általában tagbaszakadt, magas Brünhildák; ezekhez képest mi kispisták vagyunk.

Az ilyen módon előálló új jelentés az azt használók fejében szintén behuzalozódhat, $\mathrm{s}$ a tulajdonnévi reprezentációval jórészt átfedő hálózatként müködik.

\subsection{Társas jelentés}

A funkcionális kognitív közelítésmóddal megítélésem szerint magyarázható a nyelv társas beágyazottsága is. Maguk a kognitív nyelvészek is fontosnak tartják, hogy a kognitív rendszerre való fókuszáláson túl a nyelvhasználatnak erre az aspektusára is tekintettel legyenek, és olyan komplex közelítésmódot dolgozzanak ki, ami ezt is magyarázni tudja (GEERAERTS-CUYCKENS 2007: 15-16).

A nevek, illetve általában a szavak jelentésének problematikája kapcsán alapvető a szociolingvisztika azon megállapítása, hogy minden nyelvi elemnek van társas jelentése: egy nyelvi forma használata a hozzá tartozó fogalmi reprezentáció aktiválásán túl informál a beszélő társadalmi helyzetéről, csoporton belüli státuszáról is. Egy ugyanazt a valóságdarabot jelölö köznyelvi vagy nyelvjárási forma közti választás információkat közöl a beszélő személyéről, a beszélőpartnerek közötti viszonyról, a beszédhelyzetről stb. is (vö. SÁNDOR 1999: 147, ACTON 2014: 24-27). A nyelvi elemek mentális reprezentációja tehát nyilvánvalóan erre 
vonatkozóan is kell, hogy információkat tartalmazzon a fogalmi, enciklopédikus jelentésen túl: adott nyelvi forma használata ugyanis csoporthoz, közösséghez (bizonyos társadalmi csoporthoz, régióhoz stb.) tartozást fejezhet ki; emellett pedig a csoporton belüli viszonyokra is utal (ti. a kommunikációs felek közötti viszonyra; ilyen szempontból nem is választható el élesen a kulturális jelentésként meghatározott ismeretelemektől). Ez a fajta társas jelentése (lásd még indexical meaning, ECKERT 2008: 454), identitásjelző funkciója a nyelvi elemeknek egy skálán jellemezhető: a nyelvi elemek egy részének aktuálisan erőteljes társas jelentése van, míg másoknak kevésbé, megint másoké pedig majdnem vagy teljesen semleges. A nyelvi szocializáció részeként ezeket az ismeretelemeket is megtanuljuk, vagyis azt, hogy bizonyos szituációkban hogyan illik, hogyan kell, hogyan lehet beszélni, milyen normák irányítanak, és ezeknek megfelelően a nyelvi változók közül melyiket kell/lehet/célszerü választanunk, hogy a kommunikáció sikeres legyen.

Mint minden nyelvi elemnek, a neveknek is fontos jellemzője, jelentés-összetevője ez a fajta társas jelentés. A különböző névformák közötti választással is folyamatosan kijelöljük a helyünket a világban, a közösségben, a beszédhelyzetben. A hivatalos helynévi forma vagy bizonyos nem hivatalos helyi formák, esetleg szleng névváltozatok közüli választással a beszélő a saját identitását, csoporthoz tartozását is jelzi. Például a kelet-magyarországi Hajdúszoboszló településnévnek számos változata van, az általánosan ismert hivatalos névforma mellett a helybeliek egymás közötti beszélgetéseikben általában nem ezt a névformát preferálják, hanem valamelyik informális változatot: Szoboszló, Szobi, Szob. Emellett több további névforma is használatban van bizonyos csoportokon belül. A Sznoboszló névforma például negatív attitüdöt fejez ki: a város ugyanis nem támogatta a szubkultúrához tartozó fiatalok extrém sportpálya létesítéséről szóló kérelmét, ezért a várost, a városvezetóséget sznobnak nevezték, ez jelenik meg a névben (GYÖRFFY 2018: 129-132). Ennek a névformának a használata tehát a névadó fiatalok csoportjához való tartozást tükrözi.

A tulajdonneveknek ez a funkciója a leghétköznapibb szituációkban is megjelenik. Azáltal például, hogy valakivel megismerkedve az illetőt Kovács úr-nak vagy Péter-nek szólítom, másként jelölöm ki a viszonyunkat, s egyúttal a saját identitásomat is (vö. HOFFMANN 2010: 54).

A kognitív nyelvészet által alkalmazott perspektiváltság fogalma, jelensége csupán részben fedi le ezt a fajta identitásjelző funkcióját a szavaknak. A perspektiváltság ugyanis — mint utaltam rá — a mindenkori beszédeseményt, a produkciót és megértést egyaránt befolyásoló tényező, melynek lényege, hogy egy tapasztalt vagy elképzelt jelenetet, dolgot vagy folyamatot többféleképpen meg lehet konstruálni fogalmilag és nyelvileg (LANGACKER 2008: 55-89, CROFTCRUSE 2004: 42, KÖVECSES-BENCZES 2010: 145, TOLCSVAI NAGY 2010: 14), a 
nyelv ugyanis perspektivikus természetü (TOMASELLO 2002: 127). A nézőpont ugyan részben a kisebb nyelvi elemek, lényegében a szavak szintjén mutatkozik meg: a különböző variánsok közötti választásban érvényesül, de alapvetően nem az identitásjelzés a funkciója. A jelenlegi kognitív nyelvészeti elméletek ugyanis a szavak kapcsán jobbára a specifikusság, a funkció szerinti változatok közötti választást vizsgálják, s nincsenek tekintettel az ugyanazon fogalmat jelölö, s csupán nyelvváltozat- vagy regiszterbeli különbséget tükröző nyelvi változókra. A névváltozatok közötti választás jelentéshordozó szerepe viszont nagyon is lényeges tulajdonságjegye a névhasználatnak, a nevek jelentésszerkezetének leírásakor tehát mindenképpen tekintettel kell lennünk erre is. Ez pedig valójában gond nélkül beépíthető a már vázolt rugalmas és komplex jelentésmodellbe: a nevek reprezentációjának részét képezik azok az ismeretek is, hogy adott forma használata mely csoporthoz köthető, s mit árul el a beszédpartnerek egymáshoz való viszonyáról stb. (Ez a fajta társas jelentés részben átfedésben van a már tárgyalt identitásjelző funkcióval, illetve a kulturális ismeretekkel.)

\section{5. Összegzés}

Megítélésem szerint a nevek jelentése — és általában a nyelvi jelentés problematikája kapcsán olyan jelentésmodellre van szükségünk, amely összeegyeztethető a tényleges nyelvhasználat sajátosságaival, illetve a nyelvi elemek, a nevek idegrendszeri reprezentációjáról feltárt eredményekkel egyaránt. Amint látható, a névhasználat számos jellemzője jól megragadható a jelenlegi kognitív szemantikai elméletekkel, ugyanakkor a névhasználat további, eddig ilyen szempontból még nem vizsgált sajátossága is magyarázható a funkcionális kognitív szemléletet, illetve a mentális rendszer flexibilis holista hálózatmodelljét alkalmazva. Mindezek fényében a nevek komplex mentális reprezentációjának a szó formájára és nyelvi használatára vonatkozó ismeretelemek mellett részét képezik a rendkívül tágan értelmezett enciklopédikus ismeretek is.

\section{Irodalom}

ACTON, ERIC K. 2014. Pragmatics and the social meaning of determiners. PhD-értekezés. Kézirat. Stanford University. URL: https://www.emich.edu/english/faculty/documents/ suthesisacton.pdf (2018. 04. 02.)

AKsholakova, Assem 2014. Proper name as a clue symbol of Identity. Procedia Social and Behavioral Sciences 112: 465-471.

AldRIN, EMILIA 2017. Names and Identity. In: CAROLE Hough szerk., The Oxford Handbook of Names and Naming. Oxford, Oxford University Press. 382-394.

BASTUJi, HÉlÉNE-PerRin, FABIEN-GARCIA-LARVEA, Luis 2002. Semantic analysis of auditory input during sleep. Studies with event related potentials. International Journal of Psychophysiology 46: 243-255. 
BERNÁTH LÁSZLÓ-RÉVÉSZ TIBOR szerk. 2002. A pszichológia alapjai. Budapest, Tertia.

BrÉDArt, Serge 2018. An Own-Name Bias on Person Memory in Twins. Names 66/1: 47-53.

BRENDler, Silvio szerk. 2016. Cognitive Onomastics. A Reader. Hamburg, Baar.

BRENNEN, TIM 2000. On the meaning of personal names for identity: a view from cognitive psychology. Names 48: 139-146.

CIEnKI, Alan 2007. Frames, Idealized Cognitive Models, and Domains. In: GeERAERTS, DIRK-CUYCKENS, HuBERT szerk., The Oxford Handbook of Cognitive Linguistics. Oxford, Oxford Univerity Press. 170-187.

Croft, William-Cruse, Alan D. 2004. Cognitive linguistics. In: Evans, VyvyanPOURSEl, StePhANIE szerk., New directions in cognitive linguistics. Amsterdam, John Benjamins. 395-420.

CRuse, Alan D. 2000. Meaning in Language. An Introduction to Semantics and Pragmatics. Oxford, Oxford University Press.

DONNEllan, KeITH 1972. Proper names and Identifying Descriptions. In: DAVIDSON, DonAlD-HARMAn, GILBERT szerk., Semantics of Natural Language. DordrechtBoston, D. Reidel Publishing Company. 356-380.

ECKERT, PENELOPE 2008. Variation and the indexical field. Journal of Sociolinguistics 12/4: 453-476.

Evans, VyVyan-Green, Melanie 2006. Cognitive Linguistics. An Introduction. Edinburgh, Edinburgh University Press.

FǍLǍUŞ, ANAMARIA-TODEA, LUMINIŢA 2017. Names and identity. Aboriginal Canadian traditions of name-giving. In: FELECAN, OLIVIU szerk., Name and Naming. Proceedings of the Fourth International Conference on Onomastics "Name and Naming". Sacred and Profane in Onomastics. Cluj-Napoca, Editura Mega-Editura Argonaut. 147-156.

FEHÉR KRISZTINA 2018. A nyelv grammatikája. A nyelvtudomány és a kognitív pszichológia határán. Debrecen, Debreceni Egyetemi Kiadó.

FORGÁCS JÓZSEF 1999. A társas érintkezés pszichológiája, Tizenkettedik kiadás. Budapest, Kairosz Kiadó.

GeERAERTS, DIRK-CUYCKEnS, Hubert 2007. Introducing Cognitive Linguistics. In: GEERAERTS, DIRK-CUYCKENS, HuBERT szerk., The Oxford Handbook of Cognitive Linguistics. Oxford, Oxford Univerity Press. 3-21.

GYŐRFFY ERZSÉBET 2018. Helynév-szociológia. Debrecen, Debreceni Egyetemi Kiadó.

HAKAlA, Ulla-SJÖBlOM, PAUlA-KANTOLA, SATU-PÄIVI 2015. Toponyms as carriers of heritage: implications for place branding. Journal of Product \& Brand Management 24/3: 263-275. URL: https://doi.org/10.1108/JPBM-05-2014-0612. (2018. 04. 02.)

HANSACK, ERnst 2004. Das Wesen des Namens. In: BRENDLER, ANDREA-BRENDLER, SILVIO szerk., Namenarten und ihre Erforschung. Ein Lehrbuch für das Studium der Onomastik. Hamburg, Baar. 51-65. 
Helleland, Botolv 2009. Place Names as Identity Markers. In: Names in MultiLingual, -Cultural, and -Ethnic Contact. Proceedings of the 23rd International Congress of Onomastic Sciences. Toronto, York University. 501-510.

HOFFMANN ISTVÁN 2010. Név és identitás. Magyar Nyelvjárások 48: 49-58.

HOFFMANN ISTVÁN 2014. Név és jelentés. In: BAUKO JÁNOS-BENYOVSZKY KRISZTIÁN szerk., A nevek szemiotikája. Nyitra-Budapest, Nyitrai Konstantin Filozófus Egyetem Közép-európai Tanulmányok Kara-Magyar Szemiotikai Társaság. 5-21.

HOLTON, GARY 2011. Landscape in Western Pantar a Papuan outliner of southern Indonesia. In: MARK, DAVID M.-TURK, ANDREW G.-BURENHUlT, NiClAS-STEA, DAVID szerk., Landscape in Language. Transdisciplinary Perspectives. AmsterdamPhiladelphia, Benjamins. 143-166.

HONBOLYGÓ FERENC 2008. Beszédészlelés, mentális lexikon, beszédmegértés, beszédprodukció. In: CSÉPE VALÉRIA-GYŐRI MIKLÓS-RAGÓ ANETT szerk., Általános pszichológia 3. Nyelv, tudat, gondolkodás. Budapest, Osiris. 59-115.

M. HoRVÁTH VIKTÓRIA 2014. A tulajdonnév mint az elöítélet forrása. Névtani Értesitő 36: 63-72.

JUSCZYK, PETER W.-MANDEL-ELMER, DENISE 1996. What's a name? How infants respond to some familiar sound patterns. URL: http://hincapie.psych.purdue.edu/Jusczyk/pdf/ Name.pdf. (2017. 08. 21.).

KIEFER, MARKUS-PUlVERMÜLler, FrIEDEMANN 2012. Conceptual representations in mind and brain. Theoretical developments, current evidencce and future directions. Cortex 48: 805-825.

KöVECSES ZolTÁN-BENCZes RéKA 2010. Kognitív nyelvészet. Budapest, Akadémiai Kiadó.

KRIPKE, SAUL A. 1972. Naming and necessity. In: DAVIDSON, DONALD-HARMAN, GILBERT szerk., Semantics of natural language. Boston, D. Reidel. 253-355.

LANGACKER, RONALD W. 1986. An Introduction to Cognitive Grammar. Cognitive Science 10: $1-40$.

LANGACKER, RONALD W. 1987. Foundation of cognitive grammar 1. Stanford, California, Stanford University Press.

LANGACKER, RONALD W. 1991. Foundation of cognitive grammar 2. Stanford, California, Stanford University Press.

LANGACKER, RONALD W. 1999. Grammar and Conceptualization. Berlin-New York, Mouton de Gruyter.

LANGACKer, Ronald W. 2008. Cognitive Grammar. A Basic Introduction. Oxford, Oxford University Press.

LÖRINCZE LAJOS 1947. Földrajzineveink élete. Budapest, Néptudományi Intézet.

MANDEL, Denise R.-JusCZYK, PETER W.-PISONI, DAVID B. 1995. Infants' recognition of the sound pattern of their own names. Psychological Science 6: 314-317.

MEDWAY, DominiC-WARNABY, GARY 2014. What's in a name? Place branding and toponymic Commodification. Environment and Planning 'A' 46: 153-167. 
Mueller, ANDREAS-Schade, MichaEL 2012. Symbols and place identity: a semiotic approach to internal place branding - case study Bremen (Germany). Journal of Place Management and Development 5/1: 81-92.

Muller, BARBARA S.-BOVET, PIERRE 2002. Performance and reaction times in monaural localization of first names in the horizontal plane. Brain \& Language 82: 1-9.

NySTRÖM, STAFFAn 2017. Names and Meaning. In: CAROLE HougH szerk., The Oxford Handbook of Names and Naming. Oxford, Oxford University Press. 39-51.

PEDERSON, ERIC 2007. Cognitive Linguistics and linguistic relativity. In: GEERAERTS, DIRK-CUYCKENS, HUBERT szerk., The Oxford Handbook of Cognitive Linguistics. Oxford, Oxford Univerity Press. 1012-1044.

Piaget, JeAn 1965. The Child's Conception of the World. Totowa-New York, Littlefield Adams.

PÜtz, MARTIN-Robinson, Justyna A.-REIF, MoniKa szerk. 2014. Cognitive Sociolinguistics. Social and cultural variation in cognition and language use. Amsterdam, Philadelphia, John Benjamins.

RESZEGI KATALIN 2009. A kognitív szemlélet lehetőségei a helynévkutatásban. A metonimikus névadás. Magyar Nyelvjárások 47: 21-41.

Reszegi KATALIN 2012. Cognitive Approach to Hungarian Toponymy. Onoma 47: 367379.

RESZEGI KATALIN 2014. A tulajdonnevek pszicho- és neurolingvisztikája. Vizsgálati szempontok és modellek a tulajdonnevek feldolgozásáról. Névtani Értesítő 36: 133-147.

RESZEGI KATALIN 2017. Pszicholingvisztika, neurolingvisztika és névkutatás. Névtani Értesitö 39: 13-32.

Reszegi Katalin 2018a. Mental Aspects of Proper Names. Onomastica Uralica 10: 149-167.

RESZEGI KATALIN 2018b. On the proper-name-to-appellative transformation. Rivista Italiana di Onomastica 24/1: 25-46.

SÁNDOR KLÁRA 1999. Szociolingvisztikai alapismeretek. In: GALGÓCZI LÁSZLÓ szerk., Nyelvtan, nyelvhasználat, kommunikáció. Szeged, JGYTF Kiadó. 135-171.

SAPAROV, ARSENY 2003. The alteration of place names and construction of national identity in Soviet Armenia. Cahiers du Monderusse 44/1: 179-198.

SJÖBLOM, PAULA 2006. A cognitive approach to the semantics of proper nouns. Onoma 41: 63-82.

J. SoltÉSz KATAlin 1979. A tulajdonnév funkciója és jelentése. Budapest, Akadémiai Kiadó.

SzABÓ T. ATTILA 1934. A helynévgyüjtés jelentősége és módszere. Magyar Nyelv 30: $160-180$.

SzILÁGYI N. SÁNDOR 1996. Hogyan teremtsünk világot? Kolozsvár, Erdélyi Tankönyvtanács.

SZILÁGYI N. SÁNDOR 2004. A jelentésvilág szerkezete. Előadás, elhangzott a Mindentudás egyeteme V. szemeszterének 11. elöadásaként, 2004. november 18-án. URL: http:// www.mindentudas.hu/szilagyi/index.html. (2012.10.10.) 
TÁTRAi SZILÁRD 2017. Pragmatika. In: TOlCSVAI NAGY GÁBOR szerk., Nyelvtan. Budapest, Osiris Kiadó. 897-1058.

TOlCSVAI NAgY GÁBOR 2008. A tulajdonnév jelentése. In: BÖlCSKEI ANDREAN. CsÁszi ILDIKÓ szerk., Név és valóság. A Károli Gáspár Református Egyetem Magyar Nyelvtudományi Tanszékének Kiadványai 1. Budapest. 30-41.

TolCsVAI NAGY GÁBOR 2010. Kognitív szemantika. Nyitra, Konstantin Filozófus Egyetem, Közép-európai Tanulmányok Kara.

TOlCSVAI NAGY GÁBOR 2013. Bevezetés a kognitív nyelvészetbe. Budapest, Osiris.

Tolcsvai NAGY GÁBOR 2015. Az ige a magyar nyelvben. Funkcionális elemzés. Budapest, Tinta Könyvkiadó.

TolCSVAi NAGY GÁBOR 2017a. Bevezetés. In: TOlCSVAI NAGY GÁBOR szerk., Nyelvtan. Budapest, Osiris Kiadó. 21-71.

Tolcsvai NAGY GÁBOR 2017b. Jelentéstan. In: Tolcsvai NAGY GÁBOR szerk., Nyelvtan. Budapest, Osiris Kiadó. 205-499.

TOMASEllo, MiCHAEL 2002. Gondolkodás és kultúra. Budapest, Osiris.

TINCOFF, RUTH-JUSCZYK, PETER W. 1999. Some beginnings of word comprehension in 6-month-olds. Psychological Science 10/2: 172-175.

TINCOFF, RUTH-JUSCZYK, PETER W. 2000. Do 6-month-olds link sound patterns of common nouns to new exemplars? Paper presented at the International Conference on Infant Studies, Brighton, UK. URL: http://hincapie.psych.purdue.edu/Jusczyk/pdf/ Common.pdf (2012.10.10.)

TVERDOTA GYÖRGY 1992. A névvarázs poétikája. Helikon 38: 410-420.

VAlEntine, TIM-Brennen, TiM-BrÉDART, SERGE 1996. The Cognitive Psychology of Proper Names. On the importance of being Ernest. London-New York, Routledge.

VAN LANGENDONCK, WILLY 1999. Neurolinguistic and syntactic evidence for basic level meaning in proper names. Functions of Language 6/1: 95-138.

VAN LANGENDONCK, WILly 2007. Theory and Typology of Proper Names. Berlin-New York, De Gruyter.

\section{The Semantic Structure of Proper Names in a Functional-Cognitive Framework}

To address the problematics related to the meaning of names (and linguistic meaning in general) we need a semantic model that is compatible both with the features of actual language use and the findings concerning the neural representation of linguistic elements and names. The paper discusses how the functional-cognitive approach may be used in this respect and how the current description (social meaning) needs to be expanded with additional considerations so that we are able to explain all aspects of name usage. This also serves to illustrate how theories and results of sociolinguistics and cognitive linguistics may be matched with each other.

Keywords: semantic structure of proper names, identifying function, type meaning, cultural meaning, social/indexical meaning, cognitive semantics 